\title{
Pediatric thyroid cancer presenting aggressive pathologic characteristics shows persistently high rates of recurrence during the past 35 years in Korea
}

\author{
Young Ah Lee ${ }^{1 *}$, Hae Woon Jung ${ }^{1}$, Hwa Young Kim', Hoonsung Choi ${ }^{2}$, Choong Ho Shin ${ }^{1}$, Sei Won Yang ${ }^{1}$, \\ Young Joo Park ${ }^{2}$
}

From 8th APPES Biennial Scientific Meeting

Darwin, Australia. 29 October - 1 November 2014

\section{Objective}

Clinicopathological characteristics at diagnosis and longterm outcomes of pediatric thyroid cancer were analyzed. Predictors for poor outcome or recurrence were investigated among pediatric papillary thyroid cancer (PTC) patients. Whether young age at diagnosis $(<20$ years $)$ was independently predictive for recurrence was investigated among PTC patients of all ages.

\section{Methods}

We evaluated 153 patients (28males) diagnosed younger than 20 years old, managed during 1980 through 2013 (median 7.0 years of duration). Good or poor outcome (persistence or recurrence) was analyzed in 126 patients followed for at least 12 months. Predictors for recurrence were analyzed among 108 pediatric PTC patients. Adult PTC patients $(n=3093)$ were finally included in Cox proportional hazards models to find predictors for recur-free survival among PTC patients of all ages.

\section{Results}

At the time of diagnosis [papillary (86.9\%), follicular (7.9\%), medullary (3.9\%) and poorly differentiated $(1.3 \%)$ ], $38.6 \%$ of multiplicity, $57.8 \%$ of extrathyroidal extension, and $66.7 \%$ of lymph node (LN) and $13.9 \%$ of lung metastasis were found. The proportions of PTC, multiplicity, extrathyroidal extension, $\mathrm{LN}$ metastasis (all for $\mathrm{P}<0.05$ ), and distant metastasis $(\mathrm{P}<0.001)$ were significantly higher

Division of Endocrinology and Metabolism, Department of Pediatrics, Seoul National University College of Medicine, Seoul, Korea

Full list of author information is available at the end of the article in younger patients at diagnosis. Forty-four of 126 patients (34.9\%) showed poor outcome. Recurrence rates at 5 and 10 years were $13.9 \%$ and $33.8 \%$ respectively. In an analysis of 108 pediatric PTC patients, the poor outcome group showed larger tumors $(2.7 \mathrm{~cm}$ vs. $2.0 \mathrm{~cm})$, higher rates of multiplicity (66.7\% vs. $30.6 \%)$ and distant metastasis (27.0\% vs. $7.7 \%$ ) than the good outcome group (all $\mathrm{P}<$ 0.01). After adjusting for sex, age at diagnosis, primary tumor size and LN metastasis, both multiplicity and primary tumor $\geq 4 \mathrm{~cm}$ (all $\mathrm{P}<0.01$ ) were independent predictors for recurrence among pediatric PTC patients. Male sex, multiplicity, LN metastasis (all $\mathrm{P}<0.001$ ), primary tumor $\geq 4 \mathrm{~cm}$ (vs. $1.0-1.9 \mathrm{~cm}$ ), and extrathyroidal extension $(\mathrm{P}<0.01$ for both) rather than age at diagnosis $(<20,20-39$, $40-59, \geq 60$ years) were independent predictors for a poor recur-free survival among PTC patients of all ages.

\section{Conclusions}

Pediatric thyroid cancer presented aggressive pathologic characteristics and showed persistently high rates of recurrence during the past 35 years in Korea. The younger onset, the more aggressive was the pathologic presentation. Among pediatric PTC patients, large tumors $(\geq 4 \mathrm{~cm})$ and multiplicity were predictive for recurrence. Among PTC patients of all ages, aggressive pathologic presentations at a young age rather than young age itself were decisive factors for recurrence.

\section{Authors' details}

${ }^{1}$ Division of Endocrinology and Metabolism, Department of Pediatrics, Seoul National University College of Medicine, Seoul, Korea. ${ }^{2}$ Division of 
Published: 28 April 2015

doi:10.1186/1687-9856-2015-S1-P100

Cite this article as: Lee et al.: Pediatric thyroid cancer presenting

aggressive pathologic characteristics shows persistently high rates of recurrence during the past 35 years in Korea. International Journal of

Pediatric Endocrinology 2015 2015(Suppl 1):P100.

Submit your next manuscript to BioMed Central and take full advantage of:

- Convenient online submission

- Thorough peer review

- No space constraints or color figure charges

- Immediate publication on acceptance

- Inclusion in PubMed, CAS, Scopus and Google Scholar

- Research which is freely available for redistribution

Submit your manuscript at www.biomedcentral.com/submit
C) Biomed Central 